Hydrology and Earth System Sciences, 7(1), 11-21 (2003) C EGU

\title{
Evaporation characteristics of wetlands: experience from a wet grassland and a reedbed using eddy correlation measurements
}

\author{
M.C. Acreman, R.J. Harding, C.R. Lloyd and D.D. McNeil \\ Centre for Ecology and Hydrology, Wallingford, OX10 8BB, UK \\ Email for corresponding author: man@ceh.ac.uk
}

\begin{abstract}
Measurements of evaporation were made from July to November 1999 using the eddy correlation method on two wetland types - wet grassland and reedbeds - in south west England. The evaporative water use of a reed bed exceeded that of the grassland wetland by $15 \%$ (or $50 \mathrm{~mm}$ over the 5 months). The evaporation rates at both sites exceed of the Penman Potential Evaporation estimates calculated for this area. The difference between sites results from the higher roughness length of the reed bed and the lower effective surface resistance of the reed/open water assemblage. At the grassland site, a significant relationship between the surface resistance and water table level has been demonstrated. The water table at this site is managed to maintain the plant diversity and allow some agricultural access. This regime specifies a water table below the surface during the summer period, which results in higher surface resistances and lower evaporation. The results have important implications for local water resources management, especially where wetlands are maintained by pumping from rivers or groundwater.
\end{abstract}

Keywords: wetlands, evaporation, eddy correlation, wet grassland, reedbed, vapour pressure, water table level

\section{Introduction}

The internationally accepted definition of "wetlands" established by the international Convention on Wetlands (commonly called Ramsar) includes a wide range of types from coral reefs to underground lakes (Davis, 1994). However, it is usually thought of as encompassing normally wet land such as marshes, bogs and mires. Over recent decades, wetlands have been recognised increasingly for their high biodiversity and amenity value and for the important hydrological functions some wetlands perform, including flood alleviation, low-flow support, nutrient cycling and groundwater recharge. This led Mitsch and Gosselink (1993) to refer to wetlands as "biological supermarkets" and "the kidneys of the landscape".

The degradation of UK wetlands, through land drainage, river embankment and groundwater abstraction, has been highlighted by government agencies (such as English Nature) and various non-governmental organisations (Acreman and José, 2000). Hence, there are many initiatives to conserve or restore wetlands including subsidies for farmers to maintain high ditch water levels (e.g. the Pevensey Levels, Sussex), water level management plans for wetlands to integrate the needs of conservation and agriculture (e.g. the Somerset Levels and Moors) and establishment of reed beds to attract rare birds such as bittern (e.g. Lakenheath in East Anglia).

Because of high wetness and often dense vegetation, evaporation from wetlands is frequently higher than, for example, agricultural land. Gasca-Tucker (2002) found that rainfall and evaporation dominated the water balance of the Pevensey Levels wetlands in Sussex. Yet evaporative processes in wetlands are poorly understood and, hence, implications for water resources of the restoration and management of wetlands are not well quantified.

This paper is based on results of evaporation studies on two wetland types: wet grasslands and reed beds, both on the Somerset Levels and Moors in south-west England. The findings have increased our understanding of processes in wetlands and have highlighted implications of wetland management. 


\section{Wetland evaporation}

Over the past decade, there has been a small number of evaporation measurements in UK wetlands. Wet grasslands in particular have been studied. Data from the Pevensey Levels in East Sussex gave evaporation rates from wet grassland of approximately $0.6 \mathrm{~mm} \mathrm{~d}^{-1}$ during a very wet period to $6.4 \mathrm{~mm} \mathrm{~d}^{-1}$ during a hot dry spell (Gasca-Tucker 2002). Gasca-Tucker and Acreman (2000) found a broad relationship between ditch water levels and evaporation, in which they assumed that ditch water level was acting as a broad surrogate for soil moisture. Gardner (1991) used eddy correlation to measure evaporation from water meadows of the River Thames at Yarnton Mead near Oxford. Evaporation rates ranged from 1 to $5.5 \mathrm{~mm} \mathrm{~d}^{-1}$. Ratios of actual to Penman potential evaporation exceeded 1 on only a few occasions, with actual evaporation around $10 \%$ greater. The potential evaporation can be calculated in a number of ways: the oldest and still widely used method is that of Penman (1948), a more recent version uses a Penman-Monteith equation with a surface resistance of $70 \mathrm{~s} \mathrm{~m}^{-1}$ and is recommended for use by FAO (Allan et al., 1998). The earlier version is frequently used here because this is most wisely quoted. In practice in the UK lowlands, there is very little difference in the values produced by the two equations (Finch and Harding, 1998).

Evaporation measurements have also been made on some reed beds. Due to greater leaf area, open water and higher aerodynamic roughness, reeds tend to evaporate more water than grass. Herbst and Kappen (1999) recorded evaporation rates exceeding $10 \mathrm{~mm} \mathrm{~d}^{-1}$ for beds of Phramites reeds in northern Germany. Fermor (1997) used phytometers (minilysimeters) to estimate evaporation rates; in north-east England (Teeside), monthly average evaporation rates of between $0.16 \mathrm{~mm}$ (in January) and $6.72 \mathrm{~mm}$ (August) were found, with values within reed stands lower than those on the margins. In south Wales (Cardiff Bay) maximum values reached $13.39 \mathrm{~mm} \mathrm{~d}^{-1}$ in phytometers outside the main reed stands.

Earlier studies of evaporation rates from the Ham Wall reed bed in Somerset, using a Bowen-ratio station, (Gilman et al., 1998) indicated that from April to July, evaporation rates were some $5 \%$ less than the potential rate (Penman, 1948). This increased to $20 \%$ greater than potential in August but fell to around 7\% greater in September. These measurements were undertaken when the reeds were first planted and short and may not reflect evaporation rates from fully grown $(>3 \mathrm{~m})$ reeds.

\section{Study sites}

The Somerset Levels and Moors form one of the UK's largest and most important wetland areas; they contain areas of high conservation importance (Special Areas of Conservation, National Nature Reserves, and Ramsar sites) and rich agricultural land. The lower Brue valley is typical of the area, with a very broad flat floodplain approximately at sea level, criss-crossed by an extensive network of drainage ditches controlled by pumping stations. The soils are dominated by loamy peats (Altcar 1 association) and fibrous acid peats (Turbary Moor association). The traditional land use on the Altcar soils is hay-making and late summer grazing of cattle, with fields separated by water-filled ditches. In some parts, further land drainage has enabled arable crops to be grown. The Turbary soils support some relict areas of raised bog and fen woodland, although commercial peat extraction has been a major activity in many areas.

Two wetland sites (Tadham Moor and Ham Wall) within the Brue valley have been instrumented to form the CEH Wetland Research Facility and are the focus of this study. Tadham Moor (Fig. 1) lies on Altcar soils about 2-3 m above sea level and is used for hay-making followed by late season grazing of cattle. Part of the Moor has been the subject of ecological and agronomic research since 1986. The experimental plots lie within a Site of Special Scientific Interest, which is owned by English Nature and the Somerset Wildlife Trust. Within several blocks of the Tadham Moor, water levels are maintained at Tier 3, for which farmers receive a subsidy. Tier 3 means that from 1 May to 30 November, ditch water levels must be not more than $30 \mathrm{~cm}$ below mean field level, whilst from 1 December to 30 April, ditch water level must be not less than mean field level so as to cause splash flooding. In the remainder of the Moor, the North Drain pumping station maintains low water levels in the winter to improve drainage. The grassland is a mosaic of mesotrophic grassland types with Centaureo-Cynosuretu cristati and Senecioni-brometum racemosi prominent. The vegetation is notably species rich with 200 species recorded in the grassland and drainage channels. The soil consists of peat to a depth of approximately $6 \mathrm{~m}$ over silty clay. The grass is generally cut for hay in July. In 1999 the field containing the meteorological equipment was cut on 6 July and the surrounding fields progressively cut over the following ten days. During September cattle graze the fields, thus the grass stays short during the late summer and autumn. This site is well suited for micrometeorological measurements, with a broadly homogenous and uninterrupted fetch in most directions in excess of $300 \mathrm{~m}$.

In 1994 a network of 60 dip-wells and ditch water level recorders was installed as part of a project to study the relationships between soil water levels and plant community diversity (Mountford and Manchester, 1999). These were, and are still, read every two weeks, though some have been 


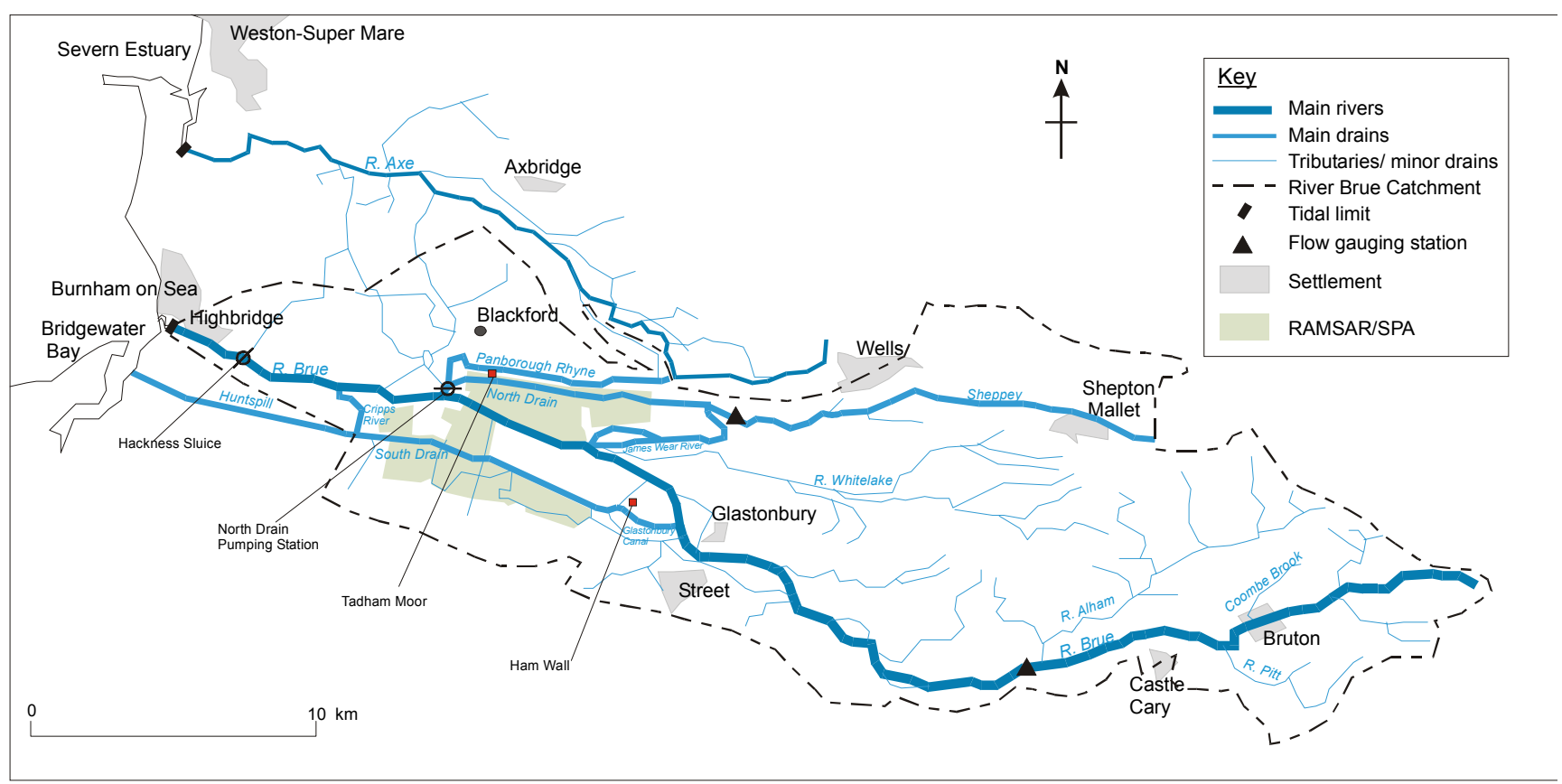

Fig. 1. Map of Somerset Levels showing Ham Wall and Tadham Moor sites

fitted with continuous recorders. The measurements of water table during 1999 (Fig. 2) contrast the high water levels in the raised water level fields (blocks 1-3) with those in the agricultural land drained by the North Drain during the winter.

Ham Wall is a former peat-extraction site on the Turbary soils from which the peat has been removed. It is now managed by the Royal Society for the Protection of Birds. Horizontal grey marine clays at $0.5 \mathrm{~m}$ AOD underlie Ham Wall. Reeds (Phragmites australis) were planted in Spring 1995 and water levels were controlled to maximise reed growth. The objective was to provide habitat for rare birds, such as bittern (Botaurus stellaris), and to demonstrate the ability of wetlands to improve water quality (by removing nitrates and phosphates). An EU grant under the LIFE Programme between 1995 and 1998 (Somerset County, 1997) provided funds for the restoration. Phases 1 and 2 cover around 40 hectares, with $80 \%$ reed and $20 \%$ open water achieved by excavation of $2 \mathrm{~m}$ deep, $5 \mathrm{~m}$ wide channels that act as break points for reed growth and provide habitat for fish. The site is thus a mosaic of reeds and open water. The reeds grow to a maximum of 3-4 $\mathrm{m}$ high during

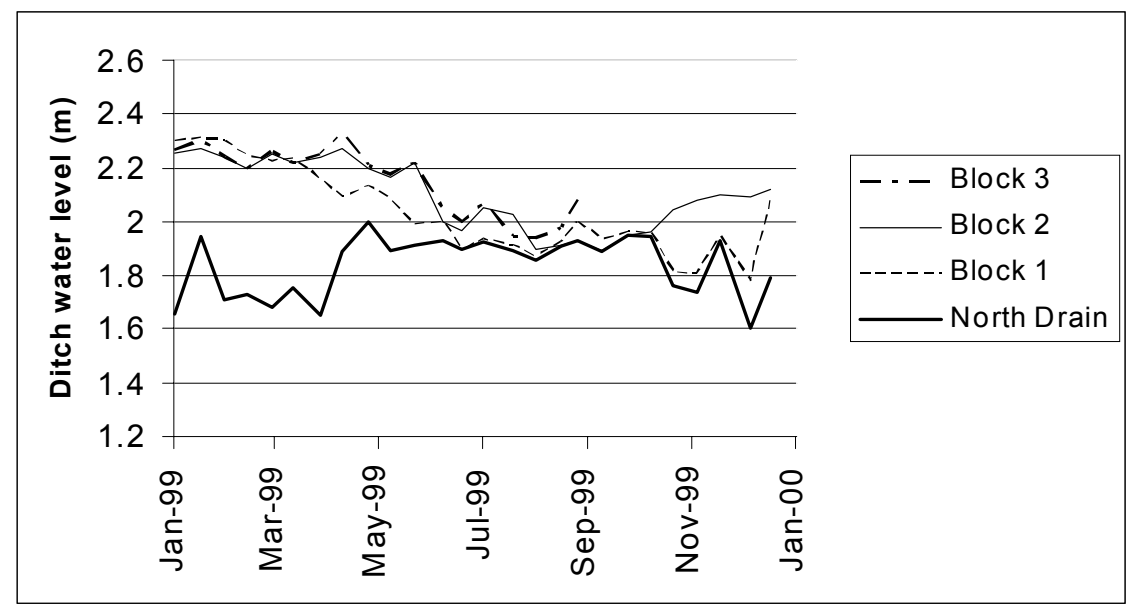

Fig. 2. Water levels measured at Tadham Moor during 1999 
the summer months; they senesce in the Autumn but remain in place structurally until mid-winter, when the dead leaves and stalks collapse. An automatic weather station and water level recorder were installed on a tower in the middle of the Phase 1 area in 1995 and evaporation measurements were started in June 1999.

\section{Equipment}

The sites were instrumented during the second half of 1999. Tadham Moor started operation on 1 July 1999 and Ham Wall on 25 June 1999. The instruments were removed on 25 November 1999. The key instrument was a Hydra Mk II system, which is a portable, open-path eddy correlation device (Shuttleworth, et al., 1988) for direct measurement of evaporation. It comprises a one-dimensional ultrasonic anemometer, a lightweight cup anemometer, a fine thermocouple and an infrared hygrometer, coupled to an on-line computer for the calculation of surface fluxes. Fluxes calculated hourly are stored along with a quality control index, which indicates when the measurement might be in error. In addition to the measurement of the fluxes of heat and water vapour, the system also provides measurements of momentum flux, net radiation, air temperature, humidity and wind speed. The measurement heights were chosen to be well above the surface roughness sub-layer. At Tadham the instrument was mounted $3 \mathrm{~m}$ above the soil surface. At this site the surface is uniform for many hundreds of metres, apart from the drainage ditches (which comprise no more that $5 \%$ of the surface) and very occasional small trees; thus this site fulfils the requirements for micro-meteorological measurements very well.

At Ham Wall the Hydra sensors were $5 \mathrm{~m}$ above the water surface and thus during the measurement period were 1 to $2 \mathrm{~m}$ above the tops of the reeds. The fetch at this site is nonuniform and thus not ideal for micro-meteorological measurements, with a variable mix of open water and reeds within the flux footprint. The reedbed extends approximately $100 \mathrm{~m}$ to the south and east, $250 \mathrm{~m}$ to the north and $500 \mathrm{~m}$ to the west (the predominant wind direction). A footprint analysis following Schmidt and Oke (1990) suggests that $70 \%$ of the flux will come from a region within $100 \mathrm{~m}$ upwind of the mast in neutral conditions and $90 \%$ in unstable condition (Table 1). The footprint will be greater than this in stable conditions. Although during stable atmospheric conditions a proportion of the flux footprint will be outside the reedbed area, during the periods of active evaporation conditions will be unstable or neutral and a large proportion of the measured flux will be coming from the reedbed. It is concluded that over a day or more the accumulated flux will be a good representation of the average evaporation.
Table 1. Distance from the mast generating 70 and $90 \%$ of observed flux from footprint analysis of the reedbed.

\begin{tabular}{lll}
\hline & $\begin{array}{l}\text { Distance } \\
\text { containing } \\
70 \% \text { of flux }\end{array}$ & $\begin{array}{l}\text { Distance } \\
\text { containing } \\
90 \% \text { of flux }\end{array}$ \\
& & \\
\hline Neutral conditions & $101 \mathrm{~m}$ & $196 \mathrm{~m}$ \\
Unstable conditions & $43 \mathrm{~m}$ & $84 \mathrm{~m}$ \\
& & \\
\hline
\end{tabular}

In addition to the eddy correlation equipment an automatic weather station was operated at each site. These stations recorded all the variables required for the Penman (1948) estimate of potential evaporation (net radiation, air temperature, humidity and wind speed) as well as rainfall, wind direction and solar radiation (see Strangeways, 1972 for more details).

\section{Data quality control and energy balance}

The flux measurements contained a substantial number of gaps and incorrect data. These are caused by malfunctioning of the system and also inevitable problems, such as rapid changes within the measurement hour and dew or rain on the sensors. Generally these problems are picked up by the system and an error code recorded. The initial quality control removed the erroneous data through the careful inspection of all data coded as "in error". In addition, a five-day period of observations from Tadham Moor was rejected. Between 12 and 16 August, the latent heat flux substantially exceeded the net radiation (at midday by a factor of two); this resulted in measured fluxes of between 10 and $20 \mathrm{~mm}$ per day. The wind speeds and radiation levels were high during this period but these high values cannot explain the evaporation rate apparently observed. No instrumental cause was found to explain this anomaly but in the analysis below these data were rejected.

Figure 3 shows the cumulative net radiation $(R n)$, sensible heat $(H)$ and latent heat (L.E) fluxes along with the cumulative energy residual (Rn-H-L.E) for Tadham Moor. These cumulative values are made up of only the hourly figures deemed to be correct by the initial quality control. Overall, the sum of sensible and latent heat fluxes exceeds the incoming net radiation by approximately $10 \%$. This small inbalance could be due either to errors in the turbulent flux and radiation measurements or to the effect of soil heat flux (the turbulent fluxes would be expected to exceed the net radiation in the second half of the year when the soil is cooling down). Overall, over $90 \%$ of the incoming net 


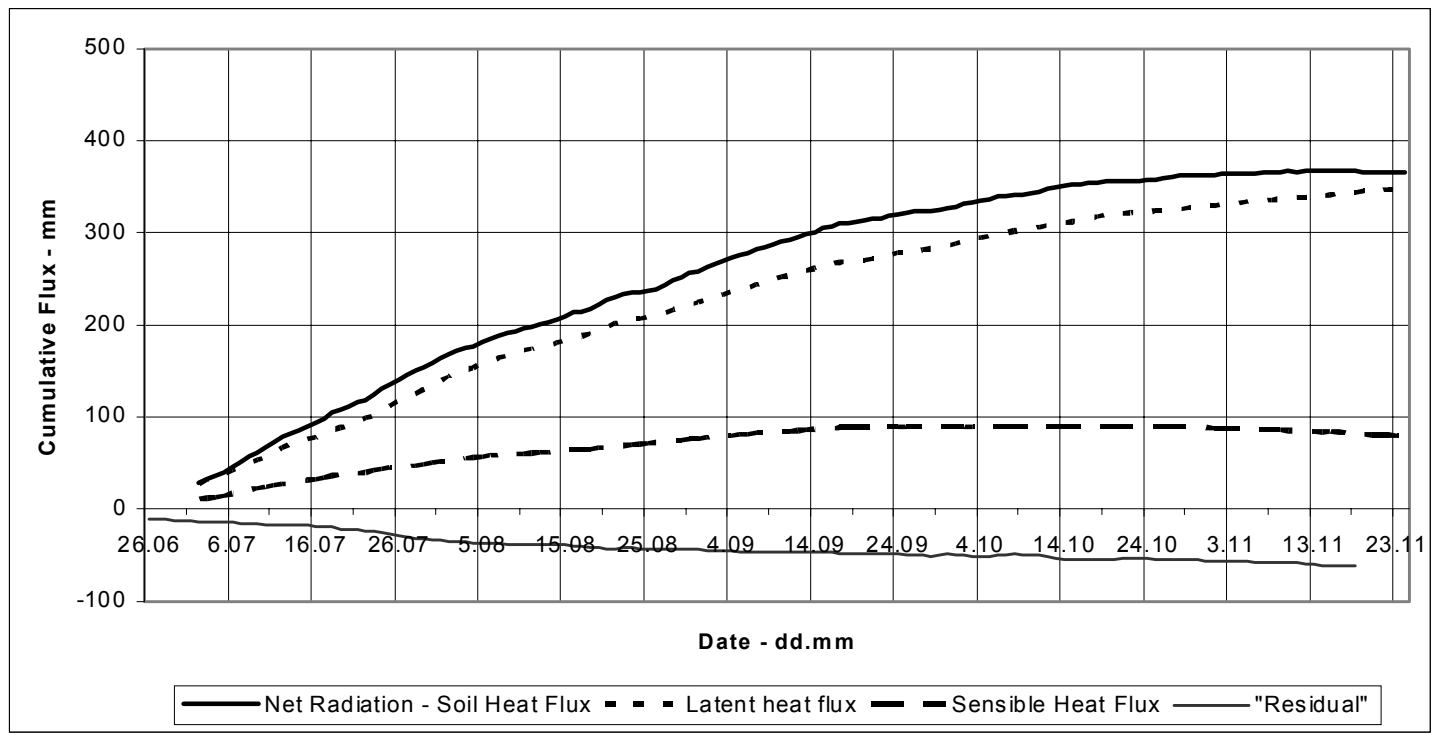

Fig. 3. Cumulative energy balance at Tadham: net radiation (Rn), latent heat flux (L.E), sensible heat flux (H) and residual (Rn-H-L.E)

radiation is used for evaporation. Also, the latent heat exceeds the net radiation in November (note the convergence of the cumulative lines in Fig. 3), with a corresponding negative sensible heat flux; this behaviour has been seen at other grassland sites in the UK (see e.g. Harding et al, 2000).

\section{Comparison of overall evaporation}

To make meaningful comparisons between the sites, a datainfilling procedure was employed. The objective here has been to produce a complete set of daily evaporation figures. This was a two stage procedure:

1. When less than five hours in a day were missing, the missing hours were filled by using the evaporative ratio (latent heat/net radiation) in adjacent hours. Occasionally at night this procedure produced rather anomalous results and in these cases a smoothed value of the evaporation was inserted.

2. When more than five hours were missing, a value calculated from the mean ratio of the evaporation and Penman potential evaporation was inserted. This ratio changed between summer and winter, so different values were used during June to September from those in October and November (Table 2).

Figure 4 shows the cumulative fluxes from Tadham Moor and Ham Wall calculated by this procedure. Clearly, the evaporation from Ham Wall exceeds that from Tadham Moor by about $50 \mathrm{~mm}$ (about 15\% higher) over this five-month period. Also, both sites exceed the Penman potential
Table 2. Ratio of daily measured evaporation to the Penman potential evaporation.

\begin{tabular}{lcc}
\hline & June to 4 Oct. & 4 Oct. to 25 Nov. \\
\hline Tadham Moor & 1.04 & 1.21 \\
Ham Wall & 1.19 & 2.92 \\
\hline
\end{tabular}

calculated for the sites and the Ham Wall evaporation exceeded the measured net radiation.

\section{Resistance values}

\section{INTRODUCTION}

To explore physical reasons for the differences between the two sites, aerodynamic and surface resistances were calculated. Aerodynamic resistance indexes the turbulence created by the vegetation, which increases with roughness length and hence the height of the crop. The surface resistance indexes the resistance to evaporation created by water passing through the soil and plant stomata. The effective surface resistance $(r$, the inverse of the surface conductance, $\left.g_{c}\right)$ is defined here by the Penman-Monteith equation (Monteith 1965):

$$
L E=\frac{\Delta A+\rho C_{P} \frac{\left(e_{s}-e_{a}\right)}{r_{a h}}}{\Delta+\gamma\left(1+\frac{r_{s}}{r_{a h}}\right)}
$$

where: 


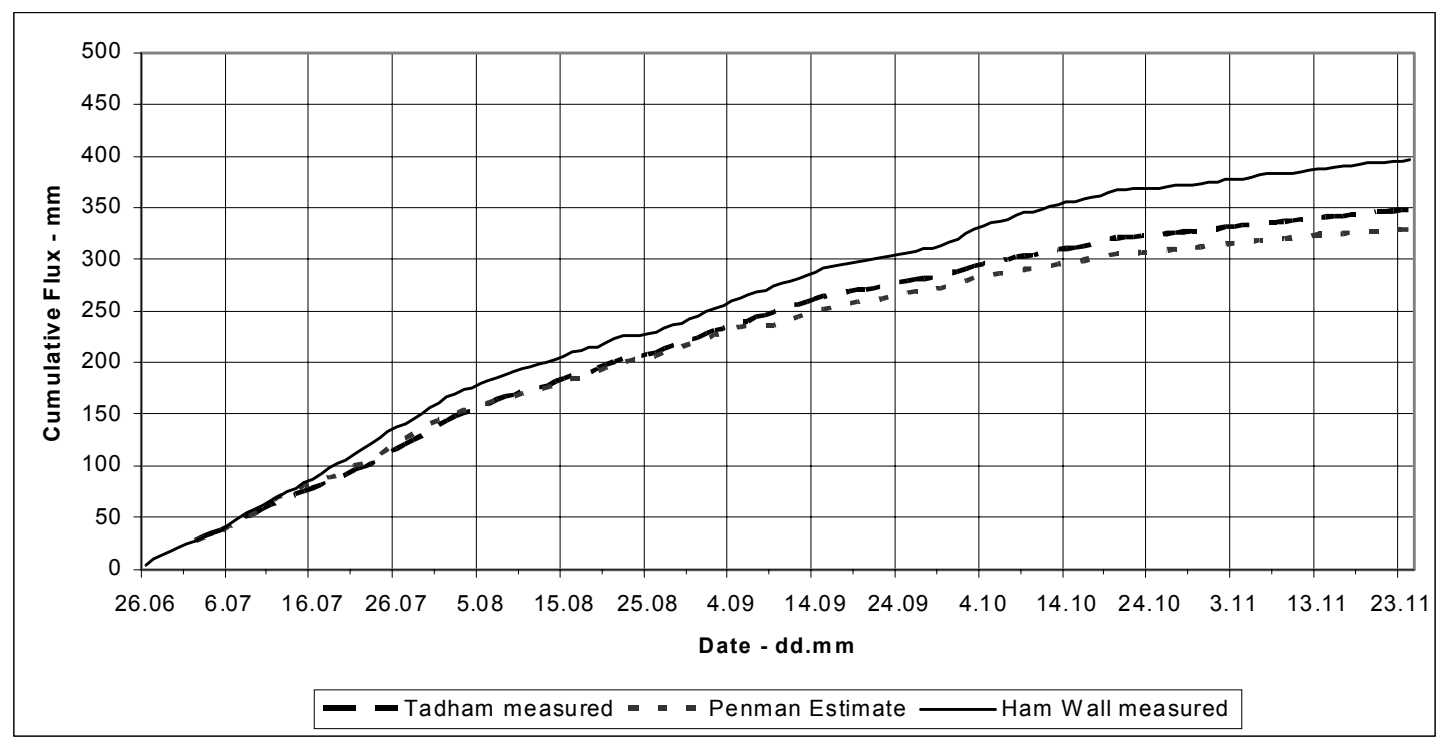

Fig. 4. Cumulative evaporation at Ham Wall and Tadham

$\mathrm{L}$ is the latent heat of vaporisation $\left(\mathrm{J} \mathrm{kg}^{-1}\right)$,

$\mathrm{E}$ is the evaporation $\left(\mathrm{kg} \mathrm{s}^{-1} \mathrm{~m}^{-2}\right)$,

$\Delta$ is the slope of the saturated vapour pressure curve

$\left(\mathrm{Pa} \mathrm{K}{ }^{-1}\right)$,

$\gamma$ is the psychrometric constant $\left(\mathrm{Pa} \mathrm{K}^{-1}\right)$,

$\mathrm{A}$ is the available energy $\left(\mathrm{W} \mathrm{m}^{-2}\right)$

$\mathrm{C}_{\mathrm{p}}$ is the specific heat of air $\left(\mathrm{J} \mathrm{kg}^{-1} \mathrm{~K}^{-1}\right)$,

$\rho$ is the density of air $\left(\mathrm{kg} \mathrm{m}^{-3}\right)$

$\mathrm{e}_{\mathrm{a}}$ is the vapour pressure $(\mathrm{Pa})$,

$\mathrm{e}_{\mathrm{s}}$ is the saturated vapour pressure at the air temperature

(Pa) and

$r_{a h}$, the aerodynamic resistance for heat and water vapour

$\left(\mathrm{s} \mathrm{m}^{-1}\right)$, which was estimated from:

$$
r_{a h}=\frac{\left(\ln \frac{z-d}{z_{0 h}}\right)^{2}}{k^{2} u}
$$

where $z_{0 h}$ is the roughness length for heat, $k$ is the von Karman's constant $(=0.4)$ and $\mathrm{u}$ the wind speed $\left(\mathrm{m} \mathrm{s}^{-1}\right)$.

\section{AERODYNAMIC RESISTANCE}

The roughness length for momentum was calculated from the measurement of momentum exchange by inverting the equation (Gash 1986):

$$
u=u_{*}\left[\ln \left(\frac{z-d}{z_{0}}\right)-\Psi\right]
$$

where: $\mathrm{u}$ is the wind speed $\left(\mathrm{m} \mathrm{s}^{-1}\right)$,

$\mathrm{u}_{*}$ is the friction velocity $\left(\mathrm{m} \mathrm{s}^{-1}\right)$,

$\mathrm{z}$ is the height of measurement $(\mathrm{m})$,

$\mathrm{d}$ is the displacement height (assumed here to be $=0.1 \mathrm{~m}$ ), $\mathrm{z}_{0}$ is the roughness length $(\mathrm{m})$ and

$\Psi$ is a stability correction for unstable conditions (see for example Paulson, 1970).

In the case of Tadham Moor, the measurement height is much greater than the displacement height and the approximation of $\mathrm{d}=0.1 \mathrm{~m}$ does not introduce a large error. For Ham Wall, the value of $d$ was chosen arbitrarily at $2 \mathrm{~m}$, although a sensitivity analysis suggested that the values of $\mathrm{z}_{0}$ calculated were not very sensitive to the value of this parameter. To avoid large errors, calculations were made only when the wind speed exceeded $1 \mathrm{~m} \mathrm{~s}^{-1}$ and $\mathrm{u}_{*}$ exceeded $0.1 \mathrm{~m} \mathrm{~s}^{-1}$. Only neutral and unstable conditions were considered. Despite these filters, the scatter of the hourly values of $\mathrm{z}_{0}$ was considerable, as was found in other studies (see e.g. Lloyd et al., 2001) and is a result primarily of the sensitivity of this method to small measurement errors. Figure 5 shows the roughness lengths and median values. There is no clear cut seasonal variation in either data set. At Ham Wall this is consistent with the observation that although the vegetation senesces in the autumn, the stalks stay erect until mid-winter (i.e. throughout the period of measurement) when they are normally flattened by strong winds. At Tadham, the hay was cut between 6 and 16 July and the grass was kept short by grazing after this: thus only the first few days of measurements were above high grass. 

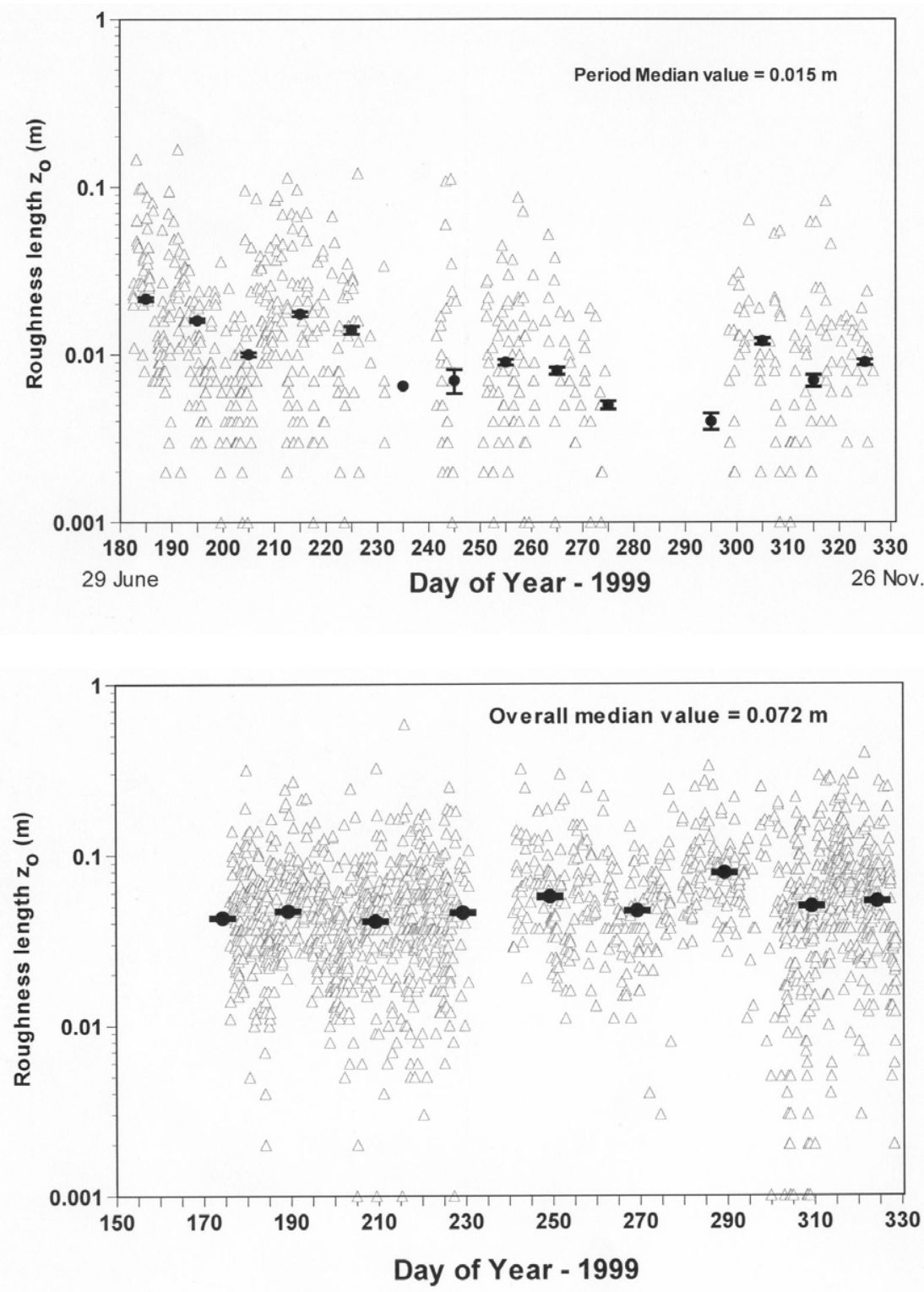

Fig. 5. Calculated roughness lengths: Tadham Moor (top), Ham Wall (bottom).

Overall, the roughness length was almost five times larger at Ham Wall (with a median value of $0.072 \mathrm{~m}$ ) compared with that at Tadham Moor (median value $0.015 \mathrm{~m}$ ).

\section{EFFECTIVE SURFACE RESISTANCE}

The effective surface resistance was calculated from the eddy correlation measurements from the two sites by inversion of Eqn. 1. The roughness length, $\mathrm{z}_{0 \mathrm{~h}}$, was estimated from the eddy correlation measurements of momentum (see above); the roughness length appropriate for heat and water vapour transport was assumed to be one-tenth that for momentum (e.g. Garratt, 1992). The absolute available energy, A, is unknown because of uncertainties in the ground heat flux. However, in this analysis, A can be equated to the sum of the measured latent and sensible heat fluxes. The calculation was made hourly to determine the diurnal and environmental responses. Only measurements coded without error were used in this calculation. In addition, calculations were not made when the latent heat was below $20 \mathrm{~W} \mathrm{~m}^{-2}$, or when the wind speed was less that $1 \mathrm{~m} \mathrm{~s}^{-1}$; these restrictions avoid, to some extent, large errors occurring in the inversion process.

Figure 6 shows the hourly and long-term mean values of calculated $r_{s}$. The scatter on the hourly values is large. This is due to both the observed dependence of $r_{s}$ on 

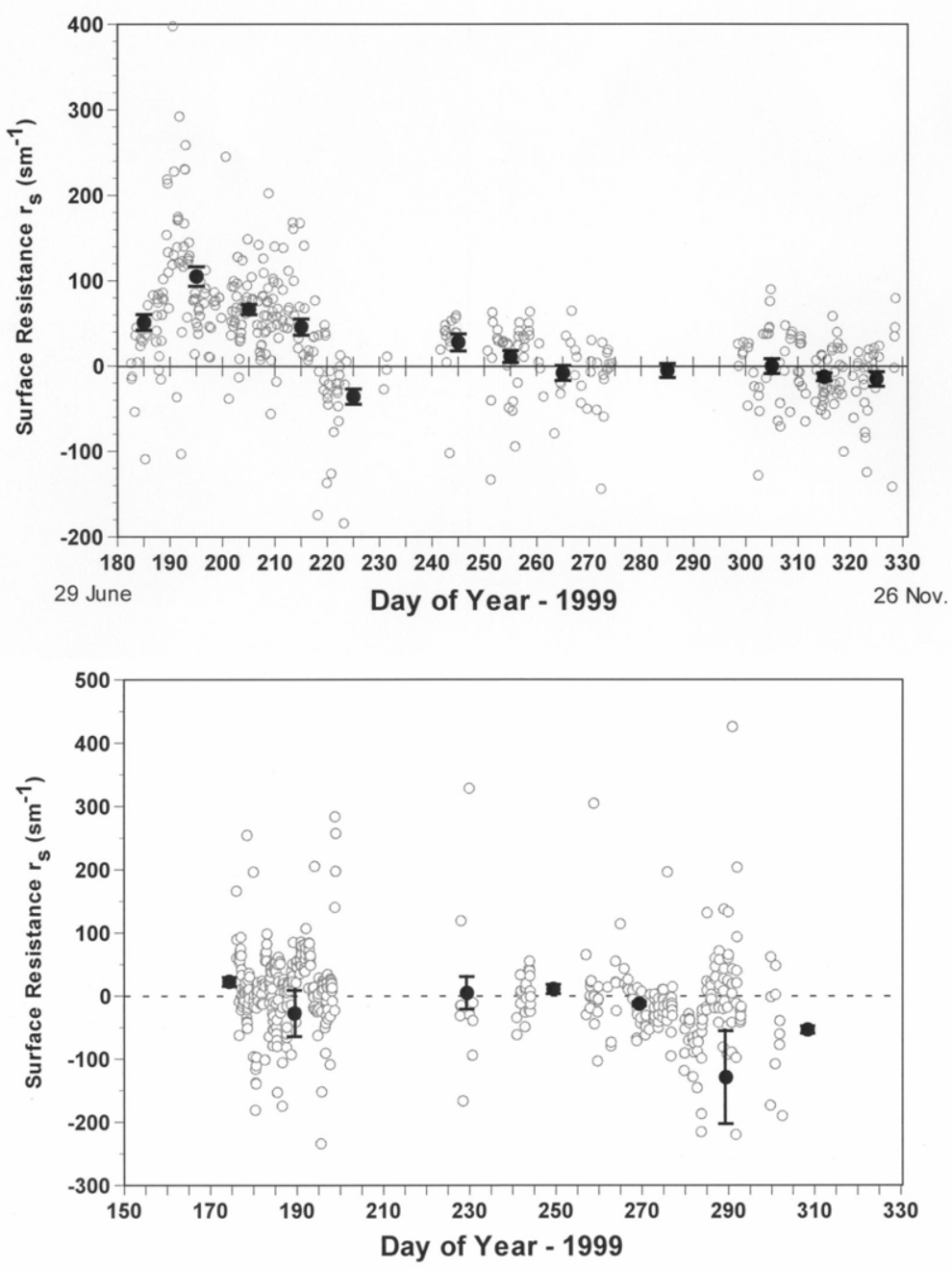

Fig. 6. Calculated surface resistance: Tadham Moor (top), Ham Wall(bottom)

environmental variables (humidity deficit, solar radiation etc.) and a considerable sensitivity of the inversion calculation on errors in the flux measurement. At Ham Wall the mean surface resistance is close to zero throughout the measurement period. At Tadham Moor a consistent picture emerges of positive values of $r_{s}$ (between 50 and $100 \mathrm{~s} \mathrm{~m}^{-1}$ ) before day 220 and zero values after day 240 . Figure 7 shows $r_{s}$ and the water level in a typical dip well for 1999. A clear relationship is evident, with high values of $r_{s}$ when the water table is deep and low when the water table is close to the surface.

The inversion of the Penman-Monteith equation to obtain surface resistance removes the direct effect of vapour pressure deficit (VPD) on evaporation. However, for forest and grassland there is frequently a residual dependence of resistance on VPD, due to the physiological response of plants closing their stomata during periods of high atmospheric demand (see e.g. Shuttleworth, 1989; Stewart and Verma, 1992). At Tadham, there is some evidence for an increase of $r_{s}$ with increasing humidity deficit (Fig. 8). The relationship is, however, most evident below a vapour pressure deficit of $0.5 \mathrm{kPa}$, with little evidence of a trend in the drier months of July and August. It seems likely that the apparent relationship in Fig. 8 is due to the coincidence of low VPDs and surface resistance values during the autumn and winter months when the water table is high.

\section{Discussion}

The evaporation from a wetland area will have a number of sources and pathways: the vegetation (through the stomata), bare soil and free water (either on the vegetation or at the surface). Evaporation will be more efficient (with a lower effective resistance) when the source is free water: when this source is unavailable, the evaporation will be subject to the physiological controls of the vegetation and soil. Clearly, therefore, the evaporation rate (and effective surface resistance) will depend on the physiological controls of the 


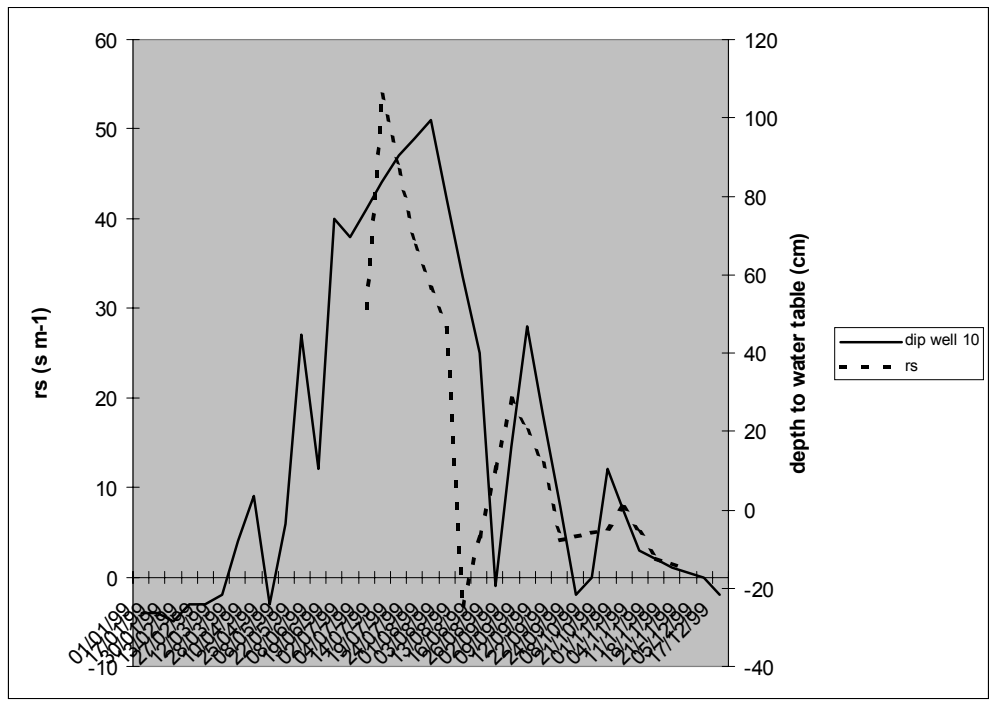

Fig. 7. Relationship between average surface resistance and water table depth at Tadham Moor

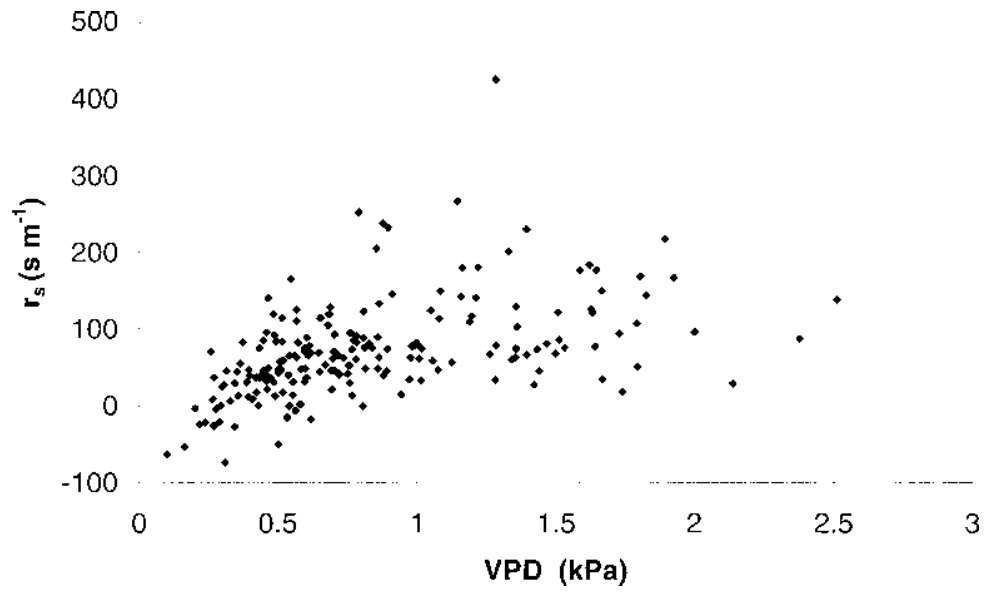

Fig. 8. Relationship between surface resistance and vapour pressure deficit

vegetation, the wetness of the vegetation and soil surface as well as the soil moisture within the root zone. Numerous studies have linked evaporation rates to soil moisture levels through surface resistance. The FAO standard value for grass $r_{s}$ is $70 \mathrm{~s} \mathrm{~m}^{-1}$ (Dorenbos and Pruitt, 1977); this is based on lysimeter studies in various parts of the world (Allen et al., 1994). Finch and Harding (2000) found this value described the evaporation very well from a grass pasture field in southern England when there was no water stress. Szeicz and Long (1969) analysed mean monthly surface resistance from ten years of data from a grass clover crop with increasing soil moisture deficit. The mean $r_{s}$ was constant at $26 \mathrm{~s} \mathrm{~m}^{-1}$ for soil matrix potential $0-350 \mathrm{KpA}$; thereafter it declined linearly to $350 \mathrm{~s} \mathrm{~m}^{-1}$ at $-1200 \mathrm{kPa}$. They offer this as a 'universal relation' for temperate climates. Similarly, Russell (1980) found an $r_{s}$ of $40 \mathrm{~s} \mathrm{~m}^{-1}$ until a soil moisture deficit (SMD) of $40 \mathrm{~mm}$ is reached; thereafter it increases to $180 \mathrm{~s} \mathrm{~m}^{-1}$ at SMD equal to $100 \mathrm{~mm}$. Many vegetation types exhibit a dependence of surface resistance on environmental variables, such as humidity deficit, temperature, radiation. Such dependences are most widely described for forests (Shuttleworth, 1989), but Stewart and Verma (1992) have described an increase of $r_{s}$ with increasing humidity deficit for a grassland in Kansas, USA. This suggests that there is potential for a self regulating (negative feedback) relationship, with high evaporation increasing humidity and resistance.

A substantial amount of research has been reported on evaporation rates from high latitude wetlands in Canada, as reviewed by Price and Waddington (2000). The Canadian wetlands comprise a huge diversity of vegetation communities ranging across sphagnum bogs, sedges and 
birch/willow communities and comparisons with wetlands in the UK must be made with caution. However, a few general conclusions are worth quoting. Resistance values of between 29 and $251 \mathrm{~s} \mathrm{~m}^{-1}$ have been reported (Lafleur and Rouse, 1988; Wessel and Rouse, 1994). Generally, evaporation rates increase (and resistance values decrease) with increasing water status and proportions of open water (Lafleur et al., 1992; Eugster et al., 2000).

Burba et al. (1999) report measurements from a Phragmites wetland in Nabraska USA. In contrast to the measurements reported here from Ham Wall, Burba found a non-zero effective surface resistance (of $100 \mathrm{~s} \mathrm{~m}^{-1}$ ) which increased when the vegetation senesced. The difference may be attributed to the fact that the Ham Wall site has significant areas of non-vegetated open water, which may dominate the evaporation.

Gavin (2001) estimated actual evaporation rates on the Emley Marshes wetlands in Kent using a Bowen Ratio station. She identified some periods with negative $r_{s}$, when actual evaporation was higher than potential values. Positive values of $r_{s}$ ranged from 3.3 to $369.9 \mathrm{~s} \mathrm{~m}^{-1}$. Low resistance was maintained down to $26 \%$ water content (matrix potential $-650 \mathrm{kPa}$, equivalent to a SMD of $40 \mathrm{~mm}$ ). Resistance then increased with SMD reaching around $370 \mathrm{~s} \mathrm{~m}^{-1}$ at $23 \%$ ( $-800 \mathrm{kPa}$ or $64 \mathrm{~mm} \mathrm{SMD).} \mathrm{However,} \mathrm{the} \mathrm{relationship}$ between SMD and resistance showed a wide scatter. The measurements and calculations presented here are entirely consistent with these published values. It appears that when the water table is below the surface, the surface resistance is close to typical grassland values with no water stress (40$70 \mathrm{~s} \mathrm{~m}^{-1}$ ). When the water table is close to or at the surface, the surface resistance tends to zero. Similarly at the reed bed, where there is always open water, the surface resistance is always close to zero.

\section{Conclusions}

The five months of measurements (July to November) indicate that the evaporative water use of a reed bed exceeds that of the nearby grassland wetland by $14 \%$ (or $50 \mathrm{~mm}$ over the five months). The evaporation rates at both sites exceed the Penman potential evaporation estimates calculated for this area. The difference between sites is a result of both the higher roughness length of the reed bed and lower effective surface resistance of the reed/open water assemblage. The grassland site shows a significant relationship between the surface resistance and water table level. The water table at this site is managed to maintain plant diversity and allow some agricultural access. The Tier 3 regime specifies a water table below the surface during the summer period, which results in higher surface resistances and lower evaporation. Water level management on grassland sites and restoration of reedbeds may have important implications for local water resources, especially where wetlands are conserved by pumping from rivers or groundwater. However, the wetlands would need to cover a large proportion of the catchment to have a significant effect on water resources at the catchment scale.

These data do not include the dormant winter period and active spring and summer periods. Therefore, the overall water balance and comparison between sites must remain uncertain. The resistance calculations suggest, however, persistent differences between the sites which will continue during the 'missing' parts of the year.

\section{References}

Acreman, M.C. and José, P., 2000. Wetlands. In: The Hydrology of the UK-a study of change, M.C. Acreman (Ed.). Routledge, London.

Allan, R.G., Pereira, L.S., Raes, D. and Smith, M., 1998. Crop evapo-transpiration: guidelines for computing crop waterrequirements. Irrigation and Drainage Paper 56, UNFAO, Rome.

Allen, R.G., Smith, M., Pereira, L.S. and Perrier, A., 1994. An update for the calculation of reference evaporation. ICID Bulletin, 43, 35-92.

Burba, G.G., Verma, S.B. and Kim, J., 1999. Surface energy balance of Phragmites australis in a prairie wetland. Agr.Forest Meteorol., 94, 31-51.

Davis, T., 1994. The Ramsar Convention Manual: a guide to the Convention on Wetlands of International Importance especially as waterfowl habitat. Ramsar Convention Bureau, Gland, Switzerland.

Dorenbos, J. and Pruitt, W.O., 1977. Guidelines for predicting crop water requirements. Irrigation and Drainage Paper 24, $2^{\text {nd }}$ edition. UN-FAO, Rome.

Eugster, W., Rouse, W.R., Pielke, R.A., McFadden, J.P., Baldocchi, D.D., Kittel, T.G.F., Chapin, F.S., Liston, G.E., Vidale, P.L., Vaganov, E. and Chambers, S., 2000. Land-atmosphere energy exchange in Arctic tundra and boreal forest: available data and feedbacks to climate. Global Change Biology, 6, 84-115.

Fermor, P., 1997. Establishment of reed bed within a created surface water fen wetland nature reserve. $\mathrm{PhD}$ thesis, University of Birmingham.

Finch, J.W. and Harding, R.J., 1998. A comparison between reference crop transpiration and measurements of evaporation for a riparian grassland site. Hydrol. Earth Syst. Sci., 2, 129 136.

Gardner, C., 1991. Water regime of river meadows: Yarnton Mead case study. Report to MAFF, Institute of Hydrology, Wallingford, $U K$.

Garratt, J.R., 1992. The atmospheric boundary layer. Cambridge University Press, UK. 316pp.

Gasca-Tucker, D., 2002. Hydrological studies of Pevensey Levels. $\mathrm{PhD}$ thesis, University of London.

Gasca-Tucker, D. and Acreman, M., 2000 Modelling ditch water levels on the Pevensey Levels wetland, a lowland wet grassland wetland in East Sussex, UK. Phys. Chem. Earth, 25, 593-597.

Gash, J.H.C., 1986. Observations of turbulence downwind of a forest-heath interface. Boundary Layer Meteorol., 36, 227-237. 
Gavin, H., 2001. Wetland hydrology and Elmley Marshes. $\mathrm{PhD}$ thesis, University of London.

Gilman, K., Hudson, J.A. and Crane, S.B., 1998. Final Report on hydrological evaluation of reed-bed re-creation at Ham Wall, Somerset. LIFE Project 92-1/UK/026.

Harding, R.J., Huntingford, C. and Cox, P.M., 2000. Transpiration from a pasture field in southern United Kingdom: long term modelling and comparison to data. Agr. For. Meteorol., 100, 309-322.

Herbst, M. and Kappen, L., 1999. The ratio of transpiration versus evaporation in a reed belt as influenced by weather conditions. Aquat. Bot., 63, 113-125.

Lafleur, P.M. and Rouse, W.R., 1988. The influence of surface cover and climate on energy partitioning and evaporation in a subarctic wetland. Boundary Layer Meteorol., 44, 327-347.

Lafleur, P.M., Rouse, W.R. and Carlson, D.W., 1992. Energybalance differences and hydrologic impacts across the northern treeline. Int. J. Climatol, 12, 193-203.

Lloyd, C.R., Harding, R.J., Friborg, T, and Aurela, M., 2001. Measurements of surface fluxes of heat and water vapour from sites in the European Arctic. Theoretical and Applied Climatol., 70, 19-35.

Monteith, J.L., 1965. Evaporation and the environment. Symp. Soc. Expl. Biol., 19, 205-234.

Mitsch, W.J. and Gosselink, J.G., 1993. Wetlands. Van Nostrand Reinhold, New York. 2nd Edition.

Mountford, O.M. and Manchester, S.J. (Eds.), 1999. Assessment of the affects of managing water levels to enhance ecological diversity. Final Report to MAFF. BD1301. Centre for Ecology and Hydrology, Monks Wood, UK.

Paulson, C.A., 1970. The mathematical representation of wind speed and temperature profiles in the unstable atmospheric surface layer. J. Appl. Meteorol., 9, 857-861.
Penman, H.L., 1948. Natural evaporation from open water, bare soil and grass. Proc. Roy. Soc. Lon, Ser A. 193, 120-145.

Price, J.S. and Waddington, J.M., 2000. Advances in Canadian wetland hydrology and biogeochemistry. Hydrol Process., 14, 1579-1589.

Russell, G., 1980. Crop evaporation, surface resistance and soil water status. Agr. Meteorol., 21, 213-226.

Schmidt, H.P. and Oke T.R., 1990. A model to estimate the source area contributing to turbulent exchange in the surface-layer over patchy terrain. Quart. J. Roy. Meteorol. Soc., 116, 965-988 Part A.

Shuttleworth, W.J., 1989. Micrometeorology of temperate and tropical forest. Phil., Trans, Roy. Soc. Lon. B., 324, 299-334.

Shuttleworth, W.J., Gash, J.H.C., Lloyd, C.R., McNeil, D.D., Moore, C.J. and Wallace, J.S., 1988. An integrated micrometeorological system for evaporation measurement. Agric. Forest Meteorol. 43, 295-317.

Somerset County Council, 1997. Guidelines for constructing reedbeds for environmental improvement applications. LIFE Project 92-1/UK/026. Somerset County Council.

Stewart, J.B. and Verma, S.B., 1992. Comparison of surface fluxes and conductances at two contrasting sites within the FIFE area. J. Geophys. Res., 97, 18623-18628.

Strangeways, I.C., 1972. Automatic weather station for network operation. Weather, 27, 403-408.

Szeicz, G. and Long, I.F., 1969. Surface resistance of crop canopies Water Resour. Res., 5, 622-633.

Wessel, D.A. and Rouse, W.R., 1994. Modeling evaporation from wetland tundra. Boundary Layer Meteorol., 68, 108-130. 
